\title{
Critical Reflections on Different Trends in the Relationship between Financial Developments and Economic Growth in China
}

\author{
Bhabani Shankar Nayak ${ }^{1} \&$ Zhong Yingnan $^{2}$ \\ ${ }^{1}$ Senior Lecturer in Business Strategy, Coventry Business School, Coventry University, UK \\ ${ }^{2}$ University of Glasgow, UK \\ Correspondence: Bhabani Shankar Nayak, Senior Lecturer in Business Strategy, Coventry Business School, \\ Coventry University, UK. E-mail: bhabani79@gmail.com
}

Received: November 23, 2018

Accepted: February 22, 2019

Online Published: February 23, 2019

doi:10.5539/ijef.v11n3p89

URL: https://doi.org/10.5539/ijef.v11n3p89

\begin{abstract}
There are many burgeoning literatures dominate the debates on relationship between financial developments and economic growth in China. It has always been a contagious one. The Chinese state is making coordinated effort for the development of the financial sector for economic growth to address issues of local development. Since the reforms of 1978, the Chinese economy has witnessed rapid growth. This paper explores the relationship between financial development and economic growth in China. It argues that there is a bidirectional causality between financial development and economic growth in China.
\end{abstract}

Keywords: finance, economy, development, China

\section{Introduction}

The impact of financial development on economic growth has always been controversial among various theoretical and empirical studies. Although there are different voices in academic communities, the existing studies generally confirm the role of financial development on economic growth. There are also some empirical researches supporting such a view. King and Levine (1993), Jalilian and Kirkpatrick (2002), pointed out that financial development had a promoting effect on economic growth. By contrast, Shan, Morris, and Sun (2001), Felix and Neven (2004) argued that things are different in different countries, for example, financial development deterred economic growth in some Latin American countries. All these studies suggest that financial development has various effects on economic growth in different countries at different times and stages of development (Rioja \& Valev, 2004).

In the about 40 years of reform and opening up, China has been experiencing rapid economic growth and a vast expansion of the financial sector. Having been classified as emerging financial sector, China has been defined as "high performing economies" by the World Bank (Shan, Morris, \& Sun, 2001). Since the economic reform starting in 1978, the annual growth rate of the Chinese economy has maintained to be about 10\% (China Statistical Yearbook 2017), and the total economic output has ranked the second highest in the world. At the same time, the Chinese government has also carried out large-scale of financial reforms, which has led to the development of the financial industry. It seems that financial development goes hand in hand with the higher-speed economic growth (Jordan \& Qi, 2006). With the consistent fast-growing economy and the increasing development of the financial system, China has been drawing more and more attention as a compelling case for researchers to find the relationship between financial development and economic growth.

Since the reform and opening up of China in 1978, there are more and more metropolitan cities with high speed of economic development and social progress. The emergence and development of the metropolis not only represent the level of a country's economic growth but also become the driving force to improve the quality of domestic economic growth (Scott, 2008). At the same time, the financial industry has been developing at a higher speed, gradually contributing to the development of those metropolises and economic prosperity. Specifically, the effective operation of financial institutions provides more financing approaches for firms, which reduces the cost of firms' development and the risk of the operation (Hao, 2006). It also provides a large number of jobs and opportunities, which contributes to economic growth in many aspects. Besides, financial institutions can accumulate capital which can be invested in emerging high-tech industries, like the computer and internet, 
which can surge economic growth (ibid).

\section{Critical Reflections on Financial Development and Economic Growth}

In the literature, the causality issue between financial development and economic growth has been examined by both theoretical and empirical evidence. However, there are different conclusions of these studies on "the finance-led growth hypothesis" (Jordan \& Jianhong, 2006). Back in 1993, King and Levine pointed out that financial development could lead to economic growth, and the development of financial intermediation including the stock market and the banking system could positively associate with economic growth. A well-developed financial system plays a vitally important role in mobilizing savings and facilitating investments (Levine \& Zervos, 1998). Afterward, Arestis, Demetriade, and Luintel (2001) indicated the critical role of banks and stock markets on economic growth, and they also stressed that banks were much more important to economic growth. Jalilian and Kirkpatrick (2002) and Kang and Sawada (2000) also supported the idea that financial development led economic growth through increasing the benefits of capital investment, which can also reduce the poverty level in some developing countries. Furthermore, through the study of both developed and developing countries in different stages of development, Nourzad (2002) finds that financial deepening can increase the efficiency of productivity, thus promoting economic growth.

However, some other economists argued that economic growth could also provide more demands for financial services, which in turn can lead to a more developed financial sector (Singh \& Weisse, 1998). Further, Shan and Morris (2002) examined the causal relationship between financial development and economic growth in some developing countries and some OECD countries, supporting the fact that there existed the bi-directional causality between finance and growth, but there are no "one-size-fits-all" conclusions across countries. There is also some empirical and theoretical evidence showing that there is no causal relationship between finance and growth (Al-taimi, H., Charif et al., 2001). They do not find evidence whether financial development is affected or can influence economic growth in their selected countries. Deidda and Fattouh (2002) also presented that there is no linear relationship between finance and growth.

In those works of literature, there is a controversial debate regarding the direction of causality. On the one hand, some economists support the finance-lead-growth hypothesis. On the other hand, there is evidence of reverse causality in some countries and bidirectional causality in others. That is to say, the relationship between financial development and economic growth might be country-specific (Shan, Morris, \& Sun, 2001). And Rioja and Valev (2004) used an extensive panel data set of seventy-four countries which are at different level of economic growth covering 1961-1995 to test the relationship between financial development and economic growth. It turns out that the effect of financial development on economic growth is various in different countries, which depends on the level of financial development. In countries with the relatively low level of financial development, the effect on economic growth is uncertain. Financial development may spur economic growth or deter growth; while in countries with a higher level of financial development, there is a significant positive effect on economic growth; moreover, in countries with a significantly high level of financial development, financial development also increases growth, but not that obvious as relatively high level of financial development countries (Rioja \& Valev, 2004). They also find that financial development affects the sources of economic growth differently in developing countries and industrial countries. In developing countries which are behind "technological frontier", financial development has a strong positive influence on economic growth mainly through capital accumulation. Conversely. In industrial countries that at the technological frontier, financial development can increase the funding for innovative activities, which can lead to more considerable productivity growth (ibid).

Among those kinds of finance-growth literature, most empirical researches based on cross-country data suggests a positive relationship between financial intermediations and economic growth (Hao, 2006). The development of financial sector has the function to mobilize savings and allocate capital more efficiently, which can have a positive effect on savings decisions and promote better investments, and therefore spur economic growth in the long-run. According to Levine (2005), there are five major channels through which financial systems can influence economic growth. First, financial development can produce information about more productive investments and allocate capital more efficiently. Second, the emergence of some financial arrangements can improve corporate governance. Third, a more developed financial market can diversify risk to encourage individuals to invest in projects with higher risks and higher production efficiency. Forth, financial development can increase the rate of savings. Last, financial development can make the exchange of goods and services more accessible. Financial intermediations, regarded as the medium in the saving-investment process, play an important role in resource allocation (Zhang, Wang, L., \& Wang, S., 2012). They can acquire information at a lower cost and allocate capital from less productive investments to relatively more productive ones, which improve resource allocation (Patrick, 1966). They can also make capital allocation more efficient by changing its 
ownership and composition (ibid).

The emergence and expansion of financial intermediations represents financial development. Sound financial intermediations are efficient in obtaining more resources and the allocating capital (Hao, 2006). And Odedokun (1996) explored that financial intermediations can prosper the economy in most developing countries. besides, Becker and Knudsen (2002) stressed that the development of the banking system plays a vital role in economic growth. Furthermore, Levine and Zervos (1998) added that stock market development was also positively correlated with economic growth.

\section{Finance and Economic Growth in China}

With the rapid development of the financial sector and the fast-growing economy, China draws much interest of economists all over the world. However, the findings are quite different according to the finance-growth literature. In the view of Allen et al. (2005), the financial sector is still under-developed with the state-controlled banking system and weak stock and bonds markets, which might hinder economic growth due to the distorting nature of the government. Even though China has experienced fast economic growth for nearly fourty years, they believe there exists the negative relationship between financial development and economic growth. According to Jordan, and Qi (2006), the substantial government ownership of banks in China is believed to be one of the reasons for the slow economic growth. Hasan et al. (2009) and Boyreau-Debray (2003) also supported the negative impact of the financial sector on economic growth by using provincial data over the period from the early 1990s to the early 2000s. They attribute the adverse effect on economic growth to the banking sector's support of loss-making state-owned enterprises.

In contrast, Hao (2006) found that China's financial development did contribute to economic growth during the period 1985-1999, he also indicated that the financial sector in China contributed to economic growth by the "mobilization of savings and the substitution of loans for budget appropriation". Furthermore, Degryse and Cheng (2007) confirmed these findings, showing that the development of the banking sector in China has a significantly positive impact on economic growth. Guariglia and Poncet (2008) showed that some activities taken by the Chinese government as state intervention in finance hindered economic growth, while other activities taken to develop financial markets by the government spurred economic growth positively. Besides, data from the firm level can also indicate that the formal financial system was positively associated with firm's growth, while informal financing did not have such an effect on growth (Ayyagari et al., 2010).

However, Zhang et al. (2012) use the city-level data from 286 Chinese cities with more local information for the period 2001-2006 to suggest that financial development has a positive relationship with economic growth. They mainly focus on the period after China's access to the World Trade Organization (WTO) in 2001, which is the big difference from previous studies that only covered the years before 2001 (Zhang, Wang, L., \& Wang, S., 2012). Their findings show that the financial reform after 2001 goes in the right direction, which leads to the economic prosperity in China (ibid). And Yuan (2014) uses the data from Jiangsu province to test whether financial development can lead economic growth in a Granger causality sense. He finds that Financial Interrelation Ratio is the primary factor to lead economic growth, while Financial Efficiency and the development of capital markets have little effect on economic growth in Jiangsu province (Yuan, 2014).

Financial economists from China and abroad study the relationship between financial development and economic growth in the overall China or different regions of China and have striking findings. Hao (2006), Jordan and Qi (2006) and Zhang, Wang, L., and Wang, S. (2012) use the dataset from all regions of China to find financial development influence economic growth in China positively. Ma and Jalil (2008) launch a comparative study between China and Pakistan to find the positive and significant relationship in Pakistan but negative relationship between loans to the private sector and economic growth in China. Chen and Jiang (2018) conduct research on specific provinces and cities in western China from 2010 to 2015 to find the positive relationship between financial development and economic growth. It shows that the relationship is different in different regions at various stages of development, which is the result of different economic and financial performance of those regions. However, there are few studies on the relationship between financial development and economic growth in the metropolis and megacities of China during recent years.

In China, financial development contributes a lot to economic growth. Since the economic reform in 1978, a series of economic and financial reforms took place in China, which lead to a more deregulated financial system and a more prosperous financial market, hence spurs significant economic growth in China (Jordan \& Qi, 2006).

Before the reform, China's financial system was a mono-bank system, which restricted resource allocation extremely. The People's Bank of China functioned as both the central and commercial bank in the financial sector, and it only distributed working capital (Hao, 2006). Over the period from the economic reform in 1978 to 
1984, both the gross national income and GDP increase slowly through the liberation of prices which increases agricultural products' prices and thus raises rural household's income (Hao, 2006). Meanwhile, the rapid emergence of non-state enterprises intensifies the competition with state-owned enterprises, which increase the profit of those enterprises and increase the earnings of their employees (ibid). The increases in households' income also contribute to the increase in savings deposits during that period.

From 1984 to 1994, the Big Four state-owned commercial banks and other financial institutions were established as the new commercial banks, and foreign banks were allowed to participate in the banking sector. Further, some non-banking financial institutions emerged in the financial market. All these development in the financial institutions in this period extended loans to state-owned enterprises and intensified the competition in the financial sector. (Zhang, Wang, L., \& Wang, S., 2012) Therefore, investment and credit in the financial sector increase rapidly, and resource allocation became more efficient, which promote the steady growth of GDP.

From 1994, a series of financial reforms aiming at the more liberalized banking system has taken place. A large number of new banks appeared, and commercial banks gained more substantial autonomy of financial operation. Furthermore, restrictions on foreign banks were relaxed. All these contribute to the increase in the total financial assets in China. Meanwhile, Chinese monetary policy focused on indirect monetary control and indirect monetary instruments played an important role in credit planning (Zhang, Wang, L., \& Wang, S., 2012). However, this bank-nominated financial sector is inefficient in capital allocation. For example, a significant share of household savings, allocated mainly by the four state-owned banks, were into inefficient state sectors (Hao, 2006). These state banks also produced a large quantity of NPLs which hinder efficient performance (Iftekhar, Paul, \& Mingming, 2006).

However, after 2001 when China entered the WTO, financial liberalization process plays an important role, including the relaxation of restrictions on ownership takeovers, on foreign banks entries and interests of loans and deposits (Zhang, Wang, L., \& Wang, S., 2012). Financial liberalization can help improve the efficiency of resource allocation and boost technology innovation. Moreover, the strengthening of financial regulation and supervision can also monitor state-owned banks, improve corporate governance and alleviate NPLs problems. Furthermore, foreign banks' presence can fierce the competition, which encourages the Chinese banking sector to perform more efficiently (Zhang, Wang, L., \& Wang, S., 2012). From 2001 to 2016, Chinese GDP witnessed a significant increase and the figure in 2016 is almost 6.7 times of that in 2001 (Chinese Statistic Yearbook, 2017). The rapid economic growth is the achievement of a series of Five-Year Plan for the development of domestic economy and society.

The development of Chinese financial markets goes smoothly. In the early 1990s, the stock market began to take shape. Two stock exchanges were established, which are the Shanghai Stock Exchange and the Shenzhen Stock Exchange. As for bond markets, government bond takes a larger share than corporate bonds in China. However, the stock market capitalization and the total value of corporate bonds only account for $15.1 \%$ and $1.1 \%$ of GDP respectively. Although Chinese stock and bond markets enjoyed rapid expansion, their effect on the real economy is insignificant (Hasan, Wachtel, \& Zhou, 2009). And Hao (2006) pointed out that there are two major channels for financial sectors to promote economic growth, which are "the mobilization of household savings and the substitution of loans for budget appropriation". He also uses GMM-system estimator to testify that savings and loan/budget have the positive and significant relationship with growth regression (Hao, 2006).

Before the reform, state-owned enterprises were the primary source of government revenue, at an average of 50.1\% during 1952-1977, while household savings has been accounting an increasing share in national income after the reform (Hao, 2006). In 1993, household total financial savings only accounted for $43.02 \%$ of GDP, while the figure almost doubled in 2013, at $82.1 \%$ of GDP and household savings added up to 46703.1 billion yuan (China Financial Statistics: 2016). It appears that financial development promotes the households' savings potential and increase savings. In the meanwhile, the expansion of household savings contributes a lot to financial deepening (Hao, 2006). In 2016, household savings deposits accounted for 56.7\% of quasi-money and $38.9 \%$ of M2 (China Statistic Yearbook, 2017). The increase of quasi-money can be used as an indicator of financial development (Zhang, Wang, L., \& Wang, S., 2012). Also, the ratio of M2 to GDP used to measure financial depth has increased dramatically from $24.6 \%$ in 1978 to 208.3\% in 2016(China Financial Statistics: 2016). Therefore, financial deepening is impressive in China from 1978 to 2016.

Furthermore, in China, due to the fact that non-state enterprises have limited access to bank loans, while household savings can be converted through some informal channels into the investments of non-state enterprises which spur economic growth more efficiently than state sectors (Hao, 2006). Therefore, financial development can channel those savings into more productive and promising investment, which improves the 
efficiency of capital allocation and promotes economic growth.

With the successful process of a series financial reforms, domestic loans have expanded increasingly. The empirical research shows that domestic loans, including RMB loans, credit loans, and entrusted loans replaces state budget, becoming the larger source to finance the economy, with $10.9 \%$ of actual funds financed investment in 2016. According to Hao (2006), most self-raised funds are from loans. Therefore, we can conclude that domestic loans are the primary source of financing the economy, which can lead to economic growth, because loans need the payment of interests, which can constrain firms' budget and therefore encourage them to allocate capital to more promising investments (Hao, 2006). Empirically, Liu and Li (2001) find that domestic loans, as a means of external financial sources, are more efficient in economic growth compared to state appropriation.

\section{Financial Developments in China}

Financial development can be reflected by the increase of total financial assets, the expansion of the number of financial institutions, as well as the growth of financial efficiency which is reflected by the degree of financial contribution to the needs of economic growth (Singh, 2008). According to Goldsmith (1969), the Financial Interrelation Ratio (FIR) can be used to measure the degree of financial intensity to an economic system in that country. It refers to the ratio of the total amount of financial activities to the total amount of economic activities in a certain period, which can be expressed by the ratio of the financial assets to the wealth of the whole economy (Singh, 2008). Generally, it can be simplified as the ratio of total financial assets to the gross domestic product.

$$
F I R=(M 2+L+D) / G D P
$$

In this expression, M2 refers to broad money, L refers to the balance of loans in domestic and foreign currencies in financial institutions, D refers to the balance of savings deposit in domestic and foreign currencies in financial institutions, and GDP refers to the gross domestic product. Singh (2008) believes that financial interrelation ratio reflects the magnitude of the actual funds to the investment and can link investment and growth directly, which can be seen as a characteristic of financial development. It is universally acknowledged that finance can affect the economy through the accumulation and the usage of capital, while the main approach is financial intermediaries and financial markets.

\section{Efficiency of Financial Developments in China}

Capital formation and capital accumulation are core issues of economic growth. Without capital accumulation, there will be no economic growth. Savings is the ultimate source of capital. Whether savings can be effectively converted into investment plays an essential role in the healthy and stable development of the economy (Hao, 2006). When a country has enough amount of savings resources, and the savings resources can be converted into investment through effective channels, the country's economy can maintain healthy and stable development. On the contrary, if a country's savings resources are unreasonably distributed, or there are obstacles in the channel of converting savings into investments, economic growth will also be affected adversely (Chang, Jia, \& Wang, 2010). And McKinnon (1973) also confirmed this in the theory of financial repression: the development of most developing countries is lagging behind because of insufficient savings resources and the lack of smooth flow of savings to investment.

The efficiency of financial development refers to the efficiency of financial intermediations to absorb capital and reallocate those resources into productive investment, which can be expressed by the Loan-Deposit Ratio (LDR) (Chang, Jia, \& Wang, 2010).

$$
L D R=L / D
$$

Since indirect financing is the major way to finance the economy in China in the long run, therefore bank's lending behavior has become the dominant factor for the smooth conversion of savings into investment. Which is to say, bank lending is the main approach to transfer savings into investment (ibid). Thus, the decreasing ratio of loans to savings means that there are more and more savings not able to be transferred into investment, and the channel for allocating savings into investment is blocked. The smaller the LDR, the smaller the amount of savings converted into investment and the more inefficient of financial development.

\section{Development of Financial Markets in China}

According to Patrick (1966), one of the significant contributions of financial development to economic growth is to encourage savers to transfer their unproductive tangible assets into savings in the form of financial assets, such as the capital stock which is of higher liquidity and can achieve more productive uses. The private market mechanism can be sufficient to allocate scarce capital in their most productive uses (Patrick, 1966). It can 
achieve its functions more broadly compared with traditional financial institutions which avoid taking risks. In China, the investments for infrastructure construction, agriculture mechanism, and technological innovation are highly needed, which requires a large number of long-term funds to finance these kinds of productive investment. A well-functioning financial market can encourage people more willingly to buy long-term securities like stocks and bonds because shareholders can sell their stakes easily if they need their savings, and this can provide abundant funding to those investments (ibid).

Financial markets provide important services for economic growth, and stock markets can provide financial services which are different from banking services (Levine \& Zervos, 1998). Further, Levine and Zervos (1998) find a strong and positive connection between stock markets development and economic growth. With the continuous optimization of the financial development environment, all kinds of financial institutions including banks, securities, and insurances emerge quickly, and the scale of financial markets is getting larger (Guo \& Zhao, 2011).

Financial markets play an important role in resource allocation, providing substantial capital supply. During 2011-2015, the $12^{\text {th }}$ Five -Year Plan guided the financial market as one of the major players in the process of China's economic and social development. As the core of the capital market, the development of securities markets in Beijing from 2010 to 2016 is significant. The Chinese government data shows that the total trading volume of securities markets increased almost three times from 8757.54 billion yuan in 2010 to 23231.86 billion yuan in 2016, which indicates that the securities market in Beijing becomes more active. Stock trading and bond trading account for a large proportion of the total trading volume of securities markets in Beijing. By the end of 2016, the volume of stock trading and bond trading increases to 13589.09 billion yuan and 24068.96 billion yuan respectively.

The active insurance market also has a positive influence on economic growth, which can transfer and manage different risks more efficiently and accumulate and mobilize domestic savings into more productive uses (Arena, 2008). And Webb et al. (2002) further explained that life insurance activity can contridute to economic growth by increasing productivity. Beides, property insurance can promote economic growth by protecting individuals from taking risks in different economic activities, and provide "risk-financing choice" for firms to reduce the probability of suffering losses, which can affect investment decisions (ibid).

At the meanwhile, Arena (2008) also finds that both life and non-life insurance has an effective impact on economic growth, and there is evidence to support the large effect of non-life insurance on economic growth in developing countries. Normally, life insurance companies can provide funds to facilitate long-term investments, while non-life insurance companies usually facilitate short-term investments (Arena, 2008). Also, according to Han et al. (2010), the development of overall insurance business including life and non-life insurance plays a more important role in the process of economic growth in developing countries than in developed countries (Han et al., 2010).

In 2011, credit insurance bore the venture capital of more than 30,000 RMB in the international trade, which enabled Chinese foreign trade to develop steadily in a safe and reliable environment (Commision, 2011). Besides, the insurance industry has also created liability insurance, and the amount of liability risk is about 30 trillion, which provides the necessary conditions for social reform and enterprise innovation (ibid). Furthermore, the insurance industry is also actively involved in financial reforms. In the bonds market, insurance institutions are the second largest investors, and large amounts of funds are put into use (ibid).

More importantly, the aggravating trend of an aging population in China's economic development brings tremendous pressure on China's social security, but the development of the insurance business can provide support for the elderly care. In 2011, there are 289.91 million policyholders of endowment insurance and 473.43 million policyholders of medical insurance (ibid). It seems that the development of the insurance industry has further solved the problem of old-age care and medical care in China. Therefore, the development of insurance business has guaranteed people's livelihood, driven China's consumption level to a certain extent, stimulated people's consumption demand and led to economic development. At the same time, it has also promoted China's social security system, increased people's welfare level continuously, and made social development more harmonious.

\section{Economic structure and Growth of Total Investments in Fixed Assets in China}

The 12th Five-Year Plan (2011) insists to optimize the primary industry, strengthen the second industry, expand the tertiary industry, promote the industrial integration and develop the modern industrial system of the capital. At the end of 2016, the $13^{\text {th }}$ Five-Year Plan points out that the transformation of "full-industrial-chain" and upgrading a saturated sector are the top priority of economic development. It aims to construct an 
"innovation-led, technology-intensive" and high-grade economic structure. Recent years, financial services contribute a lot in support of emerging sectors of strategic importance and high-end manufacturing sectors.

Fixed-asset investment is the workload of building and purchasing fixed-asset activities in monetary performance, and infrastructure investment is the key factor to facilitate the rapid development of economic activities (Qin \& Song, 2009). The $12^{\text {th }}$ Five-Year Plan (2011) infers that investment is the primary force to improve economic growth. Therefore, it is important to make the coordinated development of increasing investment, promoting consumption, rising employment and improving people's livelihood. It is also important to actively adjust investment structure to expand investment in producer services industries, strategic emerging industries, high-end manufacturing, cultural industries, and tourism to increase infrastructure investment in transportation, energy and environment, and to optimize investment structure in the real estate (Beijing Government, 2011).

\section{Financial Developments, Economic Growth and Its Positive Impacts on People's Livelihood in China}

During the $12^{\text {th }}$ Five-Year Plan period, people's living standard has been improved thoroughly, with a more stable employment environment, more comprehensive public service system, smaller income gap, modern education system, improved health care and old-age service system, and a more harmonious society (Beijing Government, 2016). Consumption plays an increasingly important role in economic development. In the $12^{\text {th }}$ Five-Year Plan (2011), the government promotes rapid economic development through sustained expansion of consumption. Therefore, it is necessary to follow the guidance of the national income distribution policy to improve the income level of residents, alleviate the inequality between the rich and poor, stabilize household consumption expectations, and enhance their consuming capacity (ibid).

According to table 3.6, per capita disposable income of urban household keeps increasing from 29073 yuan in 2010 to 52530 yuan in 2016, but after deducting the price factor, the actual growth rate is $6.9 \%$, which is $0.1 \%$ lower than that in 2015. During the $12^{\text {th }}$ Five-Year Plan period, the annual actual growth rate of per capita disposable income of the urban household is $7.2 \%$, increasing by $1 \%$ in 2010 , which indicates that people's living standard is improving at a higher speed. Meanwhile, per capita disposable income of urban household is an important indicator of people's consumption capacity, the higher actual growth rate also means the higher speed of economic growth in that period. Regarding per capita consumption expenditure of urban household, the figure is 38256 yuan in 2016, increasing by $92 \%$ compared with that in 2010, which also indicates the higher speed of economic growth in Beijing from 2010 to 2016.

Besides, the employment situation is quite stable during the $12^{\text {th }}$ Five-Year Plan period, with an average of 433400 persons being newly employed in the urban area. This is the effort of the $12^{\text {th }}$ Five-Year Plan which implements affirmative employment policies by creating more employment opportunities, targeting employment supports, perfecting public employment services networks and strengthening the regulation of labor markets (Beijing Government, 2011).

\section{Conclusion}

The financial industry is the driving force for China's economic development and social progress. Currently, the Chinese financial industry has become the industry with the largest proportion of the tertiary industry, especially after the 2008 financial crisis, the development of financial industry entered into a new booming stage and has achieved excellent results. In the meanwhile, it is of great significance for the government to formulate economic and fiscal policies, aiming to provide guidance for the healthy and rapid development of metropolis and megacities represented by further spur Chinese economic growth. Moreover, there is no significant relationship between economic growth and the improvement of financial efficiency, and to some degree, the efficiency of financial development can affect economic growth adversely. It is also important to increase the capacity of the banking system to allocate resources efficiently, and to broaden financing channels to the economy with prosperous and diversified financial markets, which can increase the direct investment to the economy.

\section{References}

Allen, F., Qian, J., \& Qian, M. (2005). Law, Finance, and Economic Growth in China. Journal of Financial Economics, 77(1), 57-116. https://doi.org/10.1016/j.jfineco.2004.06.010

Al-Tamimi, H., \& M. Al-Awad, H. C. (2001). Finance and growth: Evidence from some Arab Countries. Journal of Transnational Management Development, 7, 3-18. https://doi.org/10.1300/J130v07n02_02

Arena, M. (2008). Does Insurance Market Activity Promote Economic Growth? A Cross-Country Study for Industrialized and Developing Countries. Journal of Risk \& Insurance, 75(4), 921-946. https://doi.org/10.1111/j.1539-6975.2008.00291.x 
Arestis, P., Demetriade, P., \& Luintel, K. (2001). Financial Development and Economic Growth: The Role of Stock Markets. Journal of Money, Credit and Banking, 33(1), 16-41. https://doi.org/10.2307/2673870

Ayyagari, M., Demirgüç-Kunt, A., \& Maksimovic, V. (2010). Formal versus Informal Finance: Evidence from China. Review of Financial Studies, 23(8), 3048-3097. https://doi.org/10.1093/rfs/hhq030

Becker, M., \& Knudsen, T. (2002). Schumpeter 1911: Farsighted Visions on Economic Development. American Journal of Economics and Sociology, 61(2), 387-403. https://doi.org/10.1111/1536-7150.00166

Beijing Government. (2011). The 12th Five-Year Plan for the Development of Domestic Economy and Society in Beijing (pp.1-133). Beijing: The Beijing Government.

Beijing Government. (2016). The 13th Five-Year Plan for the Development of Domestic Economy and Society in Beijing (pp.1-148). Beijing: The Beijing Government.

Beijing Municipal Bureau of Financial Work \& Beijing Municipal Commission of Development and Reform. (2016). The 13th Five-Year Plan for the Development of Financial Industry in Beijing. Working paper 265.

Beijing Municipal Bureau of Financial Work. (2016). Financial operation in Beijing in 2015. Retrieved from http://www.bjjrj.gov.cn/jrsj/c54-a1335.html

Beijing Municipal Bureau of Financial Work. (2017). Financial operation in Beijing in 2016. Retrieved from http://www.bjjrj.gov.cn/jrsj/c54-a1736.html

Beijing Municipal Bureau of Landscape and Forestry \& General Office of Capital Forestation Commission. (2015). Beijing Municipal Bureau of Landscape and Forestry \& General Office of Capital Forestation Commission. Retrieved from http://www.bjyl.gov.cn/English/

Beijing Municipal Commission of Development and Reform. (2016). Beijing Municipal Commission of Development and Reform. Retrieved from http://fgw.beijing.gov.cn/search

Boyreau-Debray, G. (2003). Financial Intermediation and Growth: Chinese Style. Working Paper Series 3027. The World Bank, Policy Research. https://doi.org/10.1596/1813-9450-3027

Chang, P., Jia, C., \& Wang, Z. (2010). Bank Fund Reallocation and Economic Growth: Evidence from China. Journal of Banking \& Finance, 34(11), 2753-2766. https://doi.org/10.1016/j.jbankfin.2010.05.015

Chen, C., Chang, L., \& Zhang, Y. (1995). The Role of Foreign Direct Investment in China's Post-1978 Economic Development. World Development, 23(4), 691-703. https://doi.org/10.1016/0305-750X(94)00143-M

Chen, H., \& Jiang, N. (2018). The Relationship Between Financial Development and Economic Growth in Western China (pp. 509-513). Jiangsu: 2018 3rd International Conference on Social Society and Economics Development.

China Insurance Regulatory Commision Beijing Bureau. (2018). China Insurance Regulatory Commision Beijing Bureau- Statistics. Retrieved from http://beijing.circ.gov.cn/web/site3/tab170/

China Insurance Regulatory Commission (2011). China Insurance Regulatory Commission-Statistics. Retrieved from http://bxjg.circ.gov.cn/web/site0/tab5179/

Degryse, H., \& Cheng, X. (2010). The Impact of Banks and Non-Bank Financial Institutions on Local Economic Growth in China. Journal of Financial Services Research, 37(2-3), 179-199. https://doi.org/10.1007/s10693-009-0077-4

Deidda, L., \& Fattouh, B. (2002). Non-linearity between finance and growth. Economics Letters, 74(3), 339-345. https://doi.org/10.1016/S0165-1765(01)00571-7

Demirguc-Kunt, A., \& Levine, R. (1999). Bank-based and market-based financial systems: Cross-country comparisons. Policy Research Working Papers, pp.1-40.

Démurger, S. (2001). Infrastructure Development and Economic Growth: An Explanation for Regional Disparities in China. Journal of Comparative Economics, 29(1), 95-117. https://doi.org/10.1006/jcec.2000.1693

Goldsmith, R. (1969). Financial structure and development (pp. 232-245). New Haven: Yale University Press

Guariglia, A., \& Poncet, S. (2008). Could Financial Distortions Be No Impediment to Economic Growth After All? Evidence from China. Journal of Comparative Economics, 36(4), 633-657. https://doi.org/10.1016/j.jce.2007.12.003

Guo, X., \& Zhao, H. (2011). Co- Integration Analysis of Development of Security Market and Economic Growth: 
A Case Study of Beijing. Research of Finance and Education, 43-47.

Han, L., Li, D., Moshirian, F., \& Tian, Y. (2010). Insurance Development and Economic Growth. The Geneva Papers on Risk and Insurance - Issues and Practice, 35(2), 183-199. https://doi.org/10.1057/gpp.2010.4

Hao, C. (2006). Development of Financial Intermediation and Economic Growth: The Chinese Experience. China Economic Review, 17(4), 347-362. https://doi.org/10.1016/j.chieco.2006.01.001

Hasan, I., Wachtel, P., \& Zhou, M. (2009). Institutional Development, Financial Deepening and Economic Growth: Evidence from China. Journal of Banking \& Finance, 33(1), 157-170. https://doi.org/10.1016/j.jbankfin.2007.11.016

Jalilian, H., \& Kirkpatrick, C. (2002). Financial development and poverty reduction in developing countries. International Journal of Finance \& Economics, 7(2), 97-108. https://doi.org/10.1002/ijfe.179

Johansen, S. (1991). Estimation and Hypothesis Testing of Cointegration Vectors in Gaussian Vector Autoregressive Models. Econometrica, 59(6), 1551-1580. https://doi.org/10.2307/2938278

Jordan, S., \& Qi, J. (2006). Does Financial Development 'Lead' Economic Growth? The Case of China. Annals of Economics and Finance, (1), 197-216.

Kang, S., \&Sawada, Y. (2000). Financial repression and external openness in an endogenous growth model. Journal of International Trade \& Economic Development, 9(4), 427-443. https://doi.org/10.1080/096381900750056858

Kaushal, L., \& Pathak, N. (2015). The Causal Relationship among Economic Growth, Financial Development and Trade Openess in Indian Economy. International Journal of Economic Perspectives, 9(2), 5-22.

King, R., \& Levine, R. (1993). Finance, entrepreneurship and growth. Journal of Monetary Economics, 32(3), 513-542. https://doi.org/10.1016/0304-3932(93)90028-E

Levine, R. (2005). Finance and Growth: Theory and Evidence. Handbook of Economic Growth, 1(A), 866-923.

Levine, R., \& Zervos, S. (1998). Stock Markets, Banks, and Economic Growth. The American Economic Review, 88(3), 537-558.

Ma, Y., \& Jalil, A. (2008). Financial Development, Economic Growth and Adaptive Efficiency: A Comparison between China and Pakistan. China \& World Economy, 16(6), 97-111. https://doi.org/10.1111/j.1749-124X.2008.00140.x

McKinnon, R. (1973). Inflation as a global problem. Journal of International Economics, 3(4), 397-398. https://doi.org/10.1016/0022-1996(73)90031-7

Nourzad, F. (2002). Financial development and productive efficiency: A panel study of developed and developing countries. Journal of Economics and Finance, 26(2), 138-148. https://doi.org/10.1007/BF02755981

Odedokun, M. (1996). Financial Policy and Efficiency of Resource Utilization in Developing Countries. Growth and Change, 27(3), 269-297. https://doi.org/10.1111/j.1468-2257.1996.tb00906.x

Patrick, H. (1966). Financial Development and Economic Growth in Underdeveloped Countries. Economic Development and Cultural Change, 14(2), 174-189. https://doi.org/10.1086/450153

Qi, F. (2011). Empirical Analysis of the Relationship Between Economic Growth and Financial Development in Beijing. Beijing Academy of Social Sciences, 1-33.

Qin, D., \& Song, H. (2009). Sources of Investment Inefficiency: The Case of Fixed-assets Investment in China. Journal of Development Economics, 90(1), 94-105. https://doi.org/10.1016/j.jdeveco.2008.06.001

Rathanasiri, R. (2012). Financial Intermediation and Economic Growth: A Comparative Study. Ph.D. Wuhan University of Technology.

Rioja, F., \& Neven, V. (2004). Does one size fit all?: A Reexamination of the Finance and Growth Relationship. Journal of Development Economics, 74(2), 429-447. https://doi.org/10.1016/j.jdeveco.2003.06.006

Rioja, F., \& Valev, N. (2004). Finance and the Sources of Growth at Various Stages of Economic Development. Economic Inquiry, 42(1), 127-140. https://doi.org/10.1093/ei/cbh049

Rousseau, P., \& Wachtel, P. (1998). Financial Intermediation and Economic Performance: Historical Evidence from Five Industrialized Countries. Journal of Money, Credit and Banking, 30(4), 657. https://doi.org/10.2307/2601123 
Scott, A. (2008). Resurgent Metropolis: Economy, Society and Urbanization in an Interconnected World. International Journal of Urban and Regional Research, 32(3), 548-564. https://doi.org/10.1111/j.1468-2427.2008.00795.x

Shan, J., Morris, A., \& Sun, F. (2001). Financial Development and Economic Growth: An Egg-and-Chicken Problem? Review of International Economics, 9(3), 443-454. https://doi.org/10.1111/1467-9396.00291

Singh, A., \& Weisse, B. (1998). Emerging stock markets, portfolio capital flows and long-term economy growth: Micro and macroeconomic perspectives. World Development, 26(4), 607-622. https://doi.org/10.1016/S0305-750X(98)00003-5

Singh, T. (2008). Financial Development and Economic Growth Nexus: A Time-series Evidence from India. Applied Economics, 40(12), 1615-1627. https://doi.org/10.1080/00036840600892886

Webb, I., Grace, M. F., \& Skipper, H. D. (2002). The Effect of Banking and Insurance on the Growth of Capital and Output. Working Paper 02, Center for Risk Management and Insurance.

Yeandle, M. (2016). The Global Financial Centres Index 20 (pp.1-56). London: Financial Centre Features.

Yuan, J. (2014). An emperical research on Jiangsu's financial development affects economic growth. Postgraduate, Hunan University.

Zhang, J., Wang, L., \& Wang, S. (2012). Financial development and economic growth: Recent evidence from China. Journal of Comparative Economics, 40(3), 393-412. https://doi.org/10.1016/j.jce.2012.01.001

\section{Copyrights}

Copyright for this article is retained by the author(s), with first publication rights granted to the journal.

This is an open-access article distributed under the terms and conditions of the Creative Commons Attribution license (http://creativecommons.org/licenses/by/4.0/). 